\title{
Working with Racially, Culturally, and Linguistically Diverse Students, Families, and Communities: Strategies for Preparing Preservice Teachers
}

\author{
Patricia A. Edwards \\ Kristen L. White \\ Michigan State University \\ USA
}

\begin{abstract}
One of the most important skills preservice teachers must develop is their ability to build on the knowledge that students bring into classrooms, particularly the knowledge that is shaped by their family, community, and cultural histories. Teacher educators prepare preservice teachers to enter the profession with up-to-date knowledge and skills for improving reading, writing, math, assessment, and other essential components to create excellent schools and responsive classrooms; yet, few prepare teachers to work with racially, culturally, and linguistically diverse students, families, and communities. While teacher educators may agree that parents are important participants in the educational process, they need to move beyond simply acknowledging the importance of parents to accepting the responsibility for preparing preservice teachers to understand the importance of engaging parents in their child's education and possess the skills to do so. In this article, the authors present a variety of strategies that teacher educators can employ to assist preservice teachers in working with families and children from cultural, ethnic, linguistic, racial, and social-class backgrounds different than their own.
\end{abstract}

Keywords: teacher education, literacy, diverse students, preservice teachers, diverse families and communities 


\section{Preparing Preserivce Teachers for Diversity}

Building on divergent experiences, the two of us, as teacher educators, discovered that we share a mutual concern that preservice teachers are not leaving professional teacher education programs prepared to teach in diverse contexts, and consequently, they do not possess the abilities to teach diverse children and work alongside diverse families. Research has long documented this phenomenon (Edwards, 2016; Edwards; 2004; Epstein, 2011; Williams, 1992). The second author (Kristen) was a student in a doctoral seminar that the first author instructed (Pat). During that semester, we developed a professional mentor (Pat)-mentee (Kristen) relationship that has evolved into a shared commitment to improving the teacher education courses we teach in order to foreground issues of diversity, parents, and families. As literacy educators, we view the relationship between families and schools as paramount to building on children's home literacies in helping children acquire school literacy.

In this article, we address the issue of providing preservice teachers with experiences designed to enhance their abilities to teach in diverse contexts and engage with diverse families from an asset-based perspective. To develop the argument for making diversity a topic woven throughout professional teacher education programs, the first author, Pat, shares her professional journey as a longtime African American scholar that includes work with teachers at Morton Professional Development School and the parent involvement initiatives that she and the teachers at the school collaboratively developed. Then, the second author, Kristen, shares her journey as an underprepared White elementary teacher in an urban school district and how those experiences led her to pursue doctoral studies. Finally, both authors propose activities that teacher educators can use for improving preservice teachers' abilities to successfully teach diverse children across diverse landscapes in collaboration with families and communities.

\section{Pat's Scholarly Journey}

One of the most prominent efforts to bring about educational reform during the last three decades in the U.S. has come from a group of 100 deans at leading colleges of education who called themselves the Holmes Group. This organization proposed a wide-ranging agenda for transforming teacher education and restructuring teacher roles within schools, expressing these ideas in two major reports, Tomorrow's Teachers (1986) and Tomorrow's Schools (1990). I joined the faculty at Michigan State University in 1989 at the height of this educational reform movement and joined these conversations.

A slogan of the Holmes Group was "teaching for conceptual understanding." Thus, I argued that focusing on family issues would help preservice teachers come to understand that "teaching for conceptual understanding" was important, but it was equally important for preservice teachers to conceptually understand something about the parents and children who are their primary stakeholders. I suggested that improving school, family, and community partnerships should be a part of every school improvement plan. Educators were responsible for writing a plan for partnerships, just as they wrote plans for improving reading, writing, math, assessment, and other essential components to create excellent schools and responsive classrooms. Preservice education programs prepared prospective teachers to enter the profession with up-to-date knowledge, skills, tools, approaches to school, family, and community partnerships (Epstein, 2001). The responsibility for preparing preservice teachers to work with families fell squarely on the shoulders of teacher educators (Williams, 1992).

The authors of the Holmes Group report Tomorrow's Schools (1990) admitted that student [and parent] diversity had received inadequate or inappropriate attention by school and university faculty members, most of whom entered education with little personal experience of 
people different from themselves. The problem is compounded by the perception of schools as the sole source of knowledge (Kochan \& Mullins, 1992). Many parents, teachers, administrators, and teacher educators fail to consider the integration of the home, school, and other environmental factors as the basis of a fusion of knowledge. Kochan and Mullins (1992) observe that "Teachers are not prepared to detect, nor deal with, differences that might exist between the family and the school. Similarly, teacher educators expressed concern that they were not adequately informed about families to address these concerns in their classes" (p. 272).

Too often this lack of shared background makes it difficult for educators to connect subject matter to the lives of their students. The inability of teaching staff to understand the lives, histories, or cultures of communities different from theirs is a factor that has it made difficult to connect home and school literacies. Researchers like Florio-Ruane (1994) have captured the essence of why preservice teachers need to learn how to work with culturally different children and their families. In noting that [preservice teachers] themselves were generally "successful pupils" in school and entered the institution "familiar with its literacy practices," she suggested that such teachers may have difficulty finding "instructional ways to assist youngsters making the transition from home to school" (p. 53).

It is challenging to provide these opportunities, particularly in teacher education courses. Williams Jr. (1992), for instance, demonstrates how complex teacher training about parental involvement truly is by outlining three tough challenges that teacher educators face: selfdevelopment challenges, challenges within the profession and with colleagues, and challenges for teaching candidates successfully. In this article, we argue that despite these challenges it is incumbent on teacher education programs to better prepare preservice teachers to work across contexts and with diverse children, families, and parents by providing them with experiences that develop notions of diversity in each course. Therefore, we address some of the challenges germane to our argument that Williams (1992) outlined and list them below:

Self-development challenges are:

- How to observe and participate in a variety of parental involvement activities at different levels of elementary schooling and in different socioeconomic, cultural, racial/ethnic, linguistic, and geographic settings.

- How to internalize the tenet that teachers must work in partnership with parents to ensure the success of students at home, at school, and in life.

- How to conceptualize and make parental involvement an integral part of the elementary teacher preparation subject areas (e.g., reading, writing, computing, social studies, etc.).

- How to become proficient and instill in prospective teachers the importance of teaching and working with parents as well as students. (pp. 250-252)

Challenges within the profession and with colleagues such as:

- How to develop a logical place(s) for incorporating parental involvement preparation into teacher education that enhances rather intrudes upon the process.

- How to facilitate the inclusion of parental involvement throughout the curriculum/coursework of elementary teacher instruction/training.

- How to minimize or eliminate the attitudes, beliefs, and practices among many teacher educators that relegate parent involvement to being at best merely an attachment to mainstream teacher preparation experiences. (pp. 252-253) 
Challenges for teaching candidates successfully could include:

- Increased opportunities and experiences for candidates that enable them to make parental involvement instruction applicable to their elementary teaching/learning efforts.

- Increased methods for and development of skills in the implementation and assessment and refinement of home/classroom/school parental involvement efforts among elementary education teacher candidates.

- Increased learning experiences for candidates that clearly connect college/universitybased parental involvement theory with school/community-based reality. (p. 253)

In addition to the complexity of training preservice teachers is the reality that many teacher educators, like public school teachers, are not adequately prepared themselves to help preservice teachers work with families (Edwards, 2016; Epstein, 2011; Williams, 1992). There is broad consensus on the importance of the family's role in education. Nearly forty years ago, Ira Gordon (1969) suggested that parental involvement in education could be traced back to Biblical times. However, after after closely examining the research literature on parent involvement, Williams Jr. (1992) argued that "the beginnings of programs to prepare teachers for integrally involving parents as partners in their children's education cannot be traced to such a historic origin" (p. 245). What he found glaringly missing from this literature were documented examples of teacher educators preparing preservice teachers to work with parents.

\section{University and Profesional Development School Partnership}

Following Williams Jr. (1992), I recognized that few examples of teacher educators help prepare preservice teachers to engage with parents existed (Edwards, 2011; Edwards, 2004; Williams, 1992 ). Because of my expertise in family, school, and community partnerships, part of my faculty load was establishing a working relationship with Morton Professional Professional Development (PDS). Thus, I began by gathering some historical information about Morton from an interview with the first PTA/PTO president. The history of the school was very critical to understanding the current patters of parent involvement.

In 1952, when Morton Elementary School was built, it served primarily middle-class, White families. These families were young first-time homeowners. The school served many purposes for them. For example, several of the community's social events were held at school. Also, the school was a place where the young families discussed national, state, and local politics, goals and aspirations for their children, and ways they could help the school better serve the needs of their children. An interview with the first Morton PTA/PTO president was quite revealing. She stated:

In 1952, because there were few obvious differences between parents and children and teachers and administrators, Morton was a place where parents and teachers worked closely together. We were able to work closely together because we were friends, neighbors, church members, and we even saw each other at the local grocery store. We shared so much in common. We had a shared sense of goals and aspirations for our children.

The PTA/PTO president's description did not resemble Morton when I arrived at the school in the early 1990s. Morton's residential community included families that were highly mobile, and lived in a nearby trailer park and the inner-city. Therfore, the ways in which teachers 
had involved parents in 1952 was not going to be the same in the 1990s. For four years, I worked with inservice teachers to explore ways to address the three challenges that Williams Jr. (1992) noted: self-development challenges, challenges within the profession and with colleagues, and challenges for teaching candidates successfully.

After four years of working at Morton, I felt that aspects of the ways in which I worked with inservice teachers could be shared with my university colleagues. More importantly, many of the strategies that emerged from this PDS work could serve as a pathway to preparing preservice teachers to work with parents. Therefore, I introduced three new directions for working with Morton families and children with both inservice teachers and university colleagues (See Figure 1).

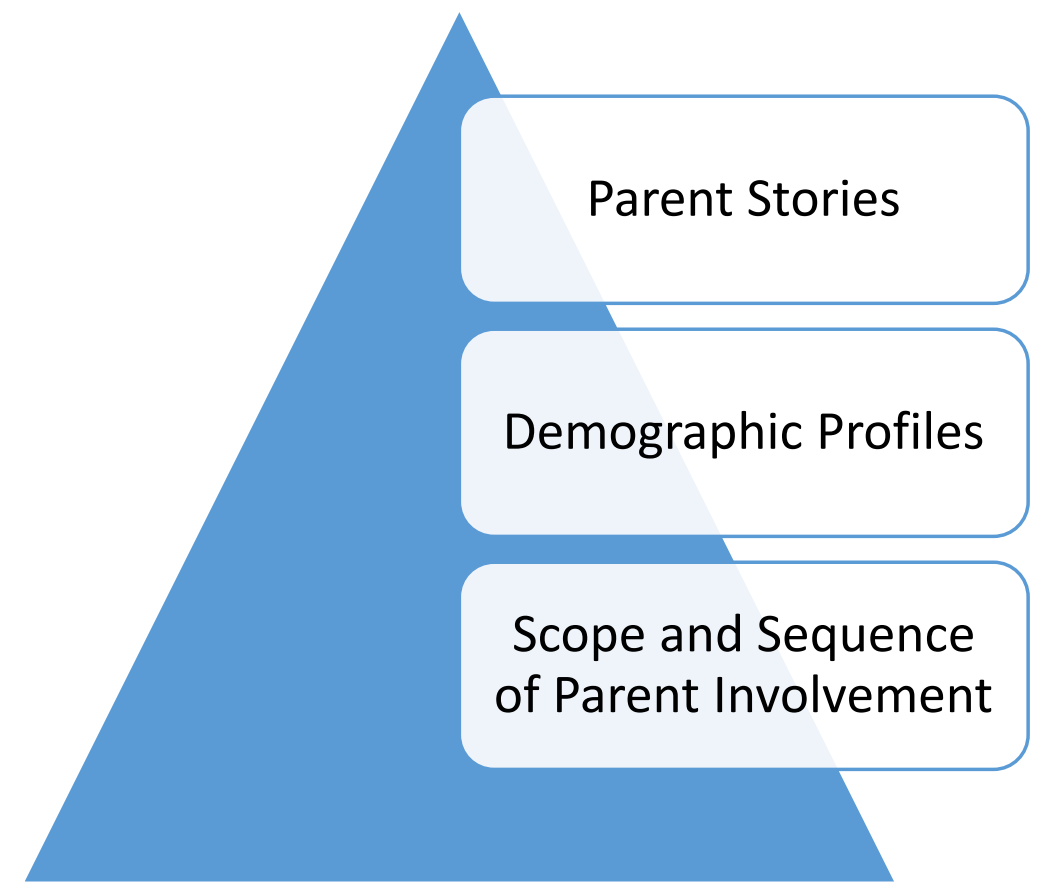

Figure 1. Early Beginning of Home Literacy Project at Morton Professional Development School

It is important to keep in mind that collaboration in the school setting requires patience, planning, and a positive attitude. For four years, I coordinated the Home Literacy Project at a Professional Development School, and I struggled to heed my own advice to be patient, plan, and stay positive. A longitudinal perspective is required to develop productive collaborations with families. Parents did not become disenfranchised overnight; therefore, schools need to have a longterm commitment to and plan for family involvement. The Home Literacy Project was designed to create a structure for parents to be involved in their children's development as readers and writers. The goals of the Home Literacy Project were to: (1) respect the multiple literacy environments the families represent; (2) become knowledgeable of the families' capability, responsibility and willingness to be involved in school; (3) help educators recognize the fact that not all parents are the same; (4) help schools reach out to families in new and different ways; and (5) to develop a scope and sequence of family involvement activities coordinated around the grade level literacy curriculum.

My work at Morton led me to conclude that many elementary school teachers are willing to admit that they expect families to attend open houses and parent-teacher conferences, but few of 
these teachers initially were prepared to admit that that they also expect families to initiate learning activities at home to improve their children's performance in school (i.e., reading to them, helping with homework, playing educational games, discussing current events, and so on; see Edwards, 1991). As time passed and I helped teachers to clarify both their goals and strategies for working with families, the teachers began to understand that family involvement at the elementary school level was associated for them with the expectation that families should support their children's literacy development (Edwards, 1991). They were asking parents to be "involved" without being clear that involvement meant not merely presence at school functions but active participation in the learning activities of the students.

After teachers have become convinced of the wisdom of family involvement, they wonder how to go about the process. A primary requisite for involving families is having the right attitude. Teachers have to want family involvement in the elementary school program; otherwise, family involvement will not be effective. A teacher must not feel threatened by families. The more confident the teacher, the less they will feel threatened. Epstein (1987), for example, has shown that within schools some teachers are 'leaders' in recruiting parent involvement (Becker \& Epstein, 1982; Epstein \& Becker, 1982). These teachers are more successful in getting parents to become involved, regardless of social class, and are also less likely than other teachers to use social class as an explanation for why parents are not involved. Instead they attribute parent involvement patterns to the strategies they did, or did not, use throughout that particular academic year. In other words, teachers who are effective in developing partnerships with parents recognize that parent involvement is a function of the knowledge and disposition they possess as teachers and not only the interest level of parents.

Success also depends on how well teachers involve families in ways that are authentic and meaningful. Shockley and her colleagues (1995) contend that family-school partnerships contribute to student success when "Parents knew that what they were doing was meaningful, saw direct benefits for their children, felt that schools were committed to them as parents, and knew that their involvement made a difference" (p. 94). I strongly believe that, just as most elementary schools have a scope and sequence of curriculum at each grade level, they also need a scope and sequence of family involvement, which is developmental, based on shared decision-making, and built around the elementary school literacy curriculum. In other words, family participation in these literacy activities is critical to their child's success. I also learned that families were comprised of busy people and that I needed to consider their work schedules and other personal and professional commitments in order to develop approaches to and expand notions of parent involvement.

\section{Recognizing Parent Differences}

Today's teachers must make a concerted effort to reach out to diverse family groups even if they do not share the same heritage (Edwards, 2004). Unfortunately, some administrators, teachers, policymakers, and researchers frequently cite low levels of parent involvement as evidence that parents do not care about their children's education or lack the ability or knowledge to support their children's learning, while others claim that the blame for low levels of parent involvement cannot be assigned to parents alone. Mapp (1997), for example, argued that "cultural, racial and economic differences between school staff and parents" (p. 36) are at the root of the misconceptions about parents' educational and family values. However, it should be noted that collaboration may not seem very natural to today's teachers who are more likely than ever in our nation's history to live in communities different and distant from where they work, speak a 
different language and represent different cultural backgrounds from their students, and may not have many natural, everyday encounters with parents (Edwards, 2016; Edwards, 2004, Edwards, Pleasants \& Franklin, 1999).

In thinking about parent involvement and developing family-school partnerships, educators must understand that parents are not all the same. Parents bring their own strengths and weaknesses, complexities, problems, and questions; because of this, teachers must work with them and see them as more than "just parents." In my work with parents, I coined two terms, differentiated parenting and parentally appropriate to help teachers find new ways to think about parents (Edwards, 2004, 2009). I propose the concept of differentiated parenting as "a way to urge schools not to place all parents into one basket" (Edwards, 2011, p. 113).

While parents might have the same goals for their children (i.e., to read, write, and spell well), they might have different ideas about how they can help their children accomplish these goals (Edwards, 2004, 2009). Parentally appropriate means that, because parents are different, tasks and activities must be compatible with their capabilities. For example, parents who do not read well might be very intimidated and frustrated by teachers who expect them to read to their children every night, and teachers might need to select other activities to support them in developing reading fluency (Edwards, 2004, 2009). Parents who work multiple jobs or who are raising their children by themselves might not be able to attend parent conferences after school or in the early evenings, and teachers might need to make other arrangements to accommodate them. When teachers plan activities and tasks designed to engage parents in collaboration and support of their child's learning, most parents will want to successfully accomplish them. Teachers might work to provide as much support as possible to assist parents in completing these activities and tasks.

\section{Previous Parent Involvement Strategies at Morton Professional Development School}

Before the Home Literacy Project began, the existing parent involvement activities at the school varied in substance and duration, much like the conventional activities described in the literature (Delgado-Gaitan, 1991; Epstein, 1987; Hess and Shipman, 1965; Laurea, 1989, 2000). At the school, when teachers solicited parent participation in classrooms, they often wanted parents to perform mechanical tasks, such as typing, editing, or binding children's stories. Such tasks offered little opportunity for significant involvement in curriculum, required the availability of parents during working hours, and involved no opportunity or expectation for reciprocity (i.e., seeking information or feedback from parents as "experts" of their children). Annual open houses and biannual parent/teacher conferences provided time for parents to see their child's classroom and get a brief overview of subject matter covered in a specific grade level. Teachers and administrators set up PTA/PTO ${ }^{1}$ meetings, held parent-teacher conferences, made home visits, and encouraged parents to attend field trips and student performances. While these events brought families and teachers together, they did not necessarily bring them together around specific literacy events or involve families in ways that would enable them to support children's literacy learning (Edwards, 1991).

\section{New Parent Involvement Structures Emerge}

Much has been written about the benefits of involving families in their children's literacy development (Edwards, 1991, 2004, 2009; Epstein, 2001; France \& Hager, 1993; Handel, 1992). A major focus of this work has centered on the question of how educators and families can better understand, cooperate, and communicate with each other in order to more effectively work together to support children's acquisition of literacy. One of the most important themes that have 
surfaced in the literature is the need for improving current structures for family involvement in schools (Edwards, 1996; Fear \& Edwards, 1995). A second important theme is that families need to be heard and given time as well as opportunity to share their ideas, questions, and insights with teachers and administrators (Lynch, 1992). Simply put, teachers, administrators, and parents should become communicating allies in the education of all children.

At the school, the home literacy project was defined as a curriculum-centered parent involvement project. The first author shared with the teachers that good teachers have always seen the importance of the parent role in their child's learning (Hollins, 1996). She encouraged the teachers to support what Etta Hollins (1996) calls "cultural accommodation." According to Hollins, "The primary goal of cultural accommodation is to facilitate teaching and learning in situations where teachers and students do not share the same culture and there is a standard curriculum. Teachers practicing cultural accommodation need to be knowledgeable about the students' cultural background" (p. 145).

Teachers have the tremendous responsibility of teaching children in school. But, we know that students have prior knowledge and experiences that they have learned from home. Since culture is a component of family life, different families enact different cultural practices, and these practices can shape the experiences and the learning of children before they enter the classroom (Edwards, McMillon, \& Turner, 2010; Heath, 1983). In what ways can teachers learn more about the familial experiences of their students, particularly if parents are not very involved with school? One way is to explore how families teach their children, and more specifically, how they engage their children in literacy activities.

Pizzo (1990) reports that parents should sustain strong attachments to their young children and advocate for them in the face of exceptionally adverse circumstances. Supporting families provides a boost to the overall development of children. It seems reasonable to conclude then that parents should be involved in their children's school curriculum. Thirty years ago, Seefeldt (1985) stated that schools should communicate with parents through the curriculum. She noted that educators should:

Capitalize on the curriculum as a means of communicating with parents. It is an ongoing way to keep parents totally informed of their child's day, the school's goals objectives, and the meaning of early childhood education. It's one way to begin to establish close, meaningful communication with busy parents ... remember-informed, involved, parents, those who are aware of what their children do in an early childhood program, are also supportive parents. (p. 25)

Researchers like Keenan, Willett and Solsken (1993) also assert that schools should communicate through the curriculum. The aims of their curriculum project were to strengthen the children's academic learning, foster school/home collaboration, and construct a multicultural community strong enough to nurture the diverse children of the urban elementary classrooms in which they worked. The authors believed that the project's focus on communication and meaning in the language arts provided a rich context for children's learning, but they also saw opportunities for further enriching their learning through new forms of parent participation in the curriculum.

Cummins (1986) argues that efforts to improve the education of children from dominated societal groups have been largely unsuccessful because the relationship between teachers and students and between schools and communities have remained unchanged. In his view, " $[t]$ he required changes involve personal redefinitions of the way classroom teachers 
interact with the children and communities they serve" (p. 18). He posits that school programs will be more successful at empowering minority children if: (1) students' language and culture are incorporated into the school program, (2) community participation is encouraged as an integral component of children's education, (3) the pedagogy promotes intrinsic motivation on the part of students to use language actively to generate their own knowledge, and (4) professionals involved in assessment become advocates for students rather than legitimizing the location of the "problem" in the students. Although, like Cummins, I was concerned with the success of children from non-dominated groups, I believe that his work speaks to school/home collaboration more generally and provides directions for raising all children in our increasingly diverse and complex villages. Unlike other approaches that focus on changes that families must make to support schools, I propose ways that schools must change to support families.

Teachers and the whole school "family" have the responsibility for encouraging and facilitating parents' exposure to and integration into their children's classroom curriculum (Beane, 1990, p. 362). According to Knapp, Turnbull, and Shields (1990), all students must learn the culture of the school while they are attempting to master academic tasks. This is especially so for the disadvantaged learner. Lyn Corno (1989) summarizes well why the home and school should communicate around curricular issues. She notes that:

With some shared understanding of their commonalities and differences, schools and homes should be able to work together to support each other in the development of a literate populace. There is, indeed, evidence that this is already occurring in certain enlightened contemporary homes and classrooms. It seems that the polarization of these subcultures may be transformed in important ways, and that families and classrooms wishing to move in this direction can benefit by a better understanding of the other's special traditions. Becoming literate about classrooms, then, is also in part becoming literate about the home; for this view suggests that effective classrooms are a blend of classroom and home — of family and knowledge workplace. (p. 41)

At Morton, in our move toward a personalized learning environment, I assisted the teachers with developing a scope and sequence of parent involvement activities grade-by-grade around curriculum issues. I shared with the teachers that even though school begins in August, very few schools provide a detailed schedule of literacy activities for parents throughout the school year in August (Edwards, 2004). As a result, parent involvement does not become a set of structured activities for families that they can expect to participate in throughout the year (Edwards, 2004). Advice to teachers included "to note that when children enter school not only are they affected by the new school environment, but their parents are as well" (Edwards, 1993, p. 1). Also, I reminded them of a statement by Fletcher (1966), referenced earlier in this paper, "Education is simply not something which is provided either by teachers in schools or by parents and family members in the home. It must be a continuing cultivation of the child's experiences in which both schools and families jointly take part (p. 189)."

Likewise, I informed teachers that I believed that a good relationship between parents, child, and teacher should be a priority. Potter (1989) echoes my position by arguing that "the teacher should strive to develop an environment where there is a participatory role for the family, which facilitates the parent-teacher-child relationship and so enables the teaching and evaluation of the child to be appropriate and just" (p. 21).

Based on my initial conversations about parents' struggles to support their children's learning, I helped the teachers organize grade level parent informant literacy group meetings ${ }^{2}$. The purpose of the face-to-face monthly group grade-level meetings was to provide an 
opportunity for teachers, parents, and myself to participate in conversations that would facilitate parent understanding of how their children were developing as readers and writers. The parent informant meetings established a predictable structure for parents to communicate information about how their children responded to instruction in school. Parents not only became more knowledgeable about the school curriculum, but they also contributed information about their children's struggles, concerns, and progress. They began to inform other parents and teachers about their children's desires and they made sense of the topics, audiences, and kernel issues in children's lives.

For example, many parents gave each other ideas about how they wrote with their children and what ideas had stirred their children's curiosity. Parents became more than recipients and overseers of assignments. Their creative responses also changed the dynamics of the informant group. There was a mutual sense of pride and enjoyment, shared by parents and educators alike. It should be noted that in addition to meeting with the grade-level groups monthly, we communicated with specific parents within these grade-level groups individually, by email, telephone, etc. This was another way we were trying to develop a personalized learning relationship with parents centered on their children's literacy development.

In addition, I encouraged the teachers to collect parent stories so that they could get an indepth understanding of how parents constructed literacy learning for their children at home ${ }^{3}$. From the information the teachers and I accrued from the grade-level parent informant literacy group meetings and from the collection of parent stories, we then organized a scope and sequence of parent involvement built around the school's curriculum (see Figure 2 for a Scope and Sequence of Curriculum-Based Parent Involvement at Morton PDS) ${ }^{4}$. In order to begin the discussion on a Scope and Sequence of Curriculum-Based Parent Involvement with an emphasis on personalized learning, I asked the teachers a series of questions: (1) What does an elementary teacher need to know at each grade level (K-5) about how to involve parents in the literacy support of their children; (2) What should be the "scope and sequence of parent involvement" around literacy from kindergarten to fifth grade; and (3) What specific literacy activities should teachers ask parents to participate in at home and/or school with their children?

Figure 2: Scope and Sequence of Curriculum-Based Parent Involvement at Morton PDS

\begin{tabular}{|c|c|}
\hline Grade Level & Parent Involvement Activity \\
\hline Kindergarten & Sharing Time \\
\hline First & Emergent Literacy \\
\hline Second & Reading and Writing Connections \\
\hline Third & Writing Process \\
\hline Fourth & Content Area Reading \\
\hline Fifth & Content Area Reading \\
\hline
\end{tabular}

Subject Matter Prepared: Culturally Unresponsive: Kristen's Journey

I attended Michigan State University's five-year elementary teacher preparation program around the time that the first author joined the faculty and the Holmes Group. After completing a year-long, post-graduate internship in a suburban school, I accepted a position as a first-grade teacher in a suburban school district adjacent to a large metropolitan Midwestern city. Unbeknownst to me at the time, the district's student population was rapidly transitioning from 
being predominately White and middle-class to linguistically, culturally, and economically diverse. Therefore, predominately White administration and teachers, including myself, worked to ensure that an increasingly diverse student body along with increased residential mobility achieved grade-level expectations in accordance with federal, state, and local policy. This small district was transitioning from a White, mostly blue-collar bedroom community to one that was urban in the sense that it was serving more African American and Latinx students, students living in poverty, and those whose first language was not English (Milner, 2013). For the first time, some of the schools in the district were qualifying for Title $1^{5}$ funds. The local community was also dealing with rising crime and racial/ethnic tension.

While serving as co-chair of the School Improvement Committee, I analyzed school data and found that about $40 \%$ of students who completed kindergarten in the building did not remain through fifth grade. For instance, during my second year of teaching I had approximately 10 students join or exit my first-grade classroom, with a maximum of 28 students and no assistance (i.e., paraprofessional). I was 23 years old at the time. Three years prior, the state of Michigan passed a law allowing charter schools. Consequently, some students were leaving the district to attend nearby charter schools and, as a result, the district was losing money. Like those around the state, the district faced new economic challenges and unforeseen competition.

When a student left the public school to attend a nearby charter, the district lost per-pupil funding from the state. Oftentimes unsatisfied with the charter school and unaware that charter schools were not held accountable to the state in the same way that public schools were, families returned to the district but, by law, the monies did not. No longer able to rely on a steady student population, the district for the first time since its inception struggled to retain teaching staff and families, as well as maintain a consistent budget. Consensus among the staff was that charter schools were recruiting the "good families." Some families commented that they were considering charter schools, private schools, as well as relocating because of the changing neighborhood. Put differently, and unconscious of it at the time, I was teaching in a context that was experiencing "White flight," which meant residents were moving to more suburban areas in pursuit of a more racially and culturally homogenous area.

Concerns about the district's economic stability, compounded with an influx of families and caregivers who were culturally and linguistically different from the teaching staff and central administration, created more tensions that were made explicit but never recognized or discussed as problematic. For example, teachers commented about the decreasing parent enrollment at PTA/PTO meetings, the lack of parent helpers in classrooms, the increase in student behavioral issues, and children not coming to school prepared for kindergarten. As a young teacher, unaware of my own Whiteness, I too was complicit in blaming the shifting population in the local community and schools that perceived families and caregivers from a deficit perspective. When parents did not volunteer in the classroom or attend parent-teacher conferences I assumed that they did not care about their children's academic achievement. If the school offered information about how to best support their child, the family was blamed if academic or behavioral progress was not immediately apparent. I became frustrated that, despite my valiant efforts to teach 28 children how to read each year, some were not successful as measured by curriculum and standardized tests. Yet I never questioned the standards set forth, the curriculum I uncritically taught, or my own personal conceptions.

Drawing on my own personal and limited experiences during undergraduate work, I had not developed what I believe to be the stance necessary for introspective reflection that would have allowed me to interrogate my attitude or dispositions toward the community, children, and 
parents/caregivers. In other words, I was not aware of how unprepared I was to teach in a community that was different than the one I lived in, nor was I adequately prepared to productively engage with linguistically, ethnically, and economically diverse families and caregivers. As I stated earlier, I felt subject-matter-prepared but culturally unresponsive. In this day and time, knowledge and skill development in subject matter instruction is simply not enough to effectively teach in the multicultural world of today's schools. Krevotics and Nussel (1994) further emphasize this point noting that:

Many teachers find themselves ill-prepared to comprehend the multiple cultures that students bring to the classroom, let alone bring dignity and respect for those cultures. They are taught subject matter, but not what to do when the subject matter does not pertain to the life experiences of the students. Teacher education programs rarely prepare teachers to make education meaningful to diverse groups of students [and their parents] (p. xi).

In retrospect, my fieldwork, including student teaching, throughout my program was in White, middle and upper-middle class schools with predominately White teachers and administrators. Additionally, I interfaced only with White instructors, apart from the few who taught some of the upper-level Spanish courses that I took in another college on campus to fulfill requirements for a Spanish minor. Upon graduation, however, the available jobs were not in districts that reflected communities that comprised my narrow set of personal and professional experiences.

When I returned to Michigan State University two decades after accepting my first teaching job, I enrolled in a Ph.D. course taught by the first author. While learning about her research in that course, I vividly remember, for the first time, openly discussing and reflecting on my own shortcomings and lack of preparation to teach in a diverse school district especially when it came to working with families and children. What has been most difficult to accept at times is that for many years I neglected to understand that I was part of the problem. However, the safe space in which initial conversations between Patricia and myself continued throughout my studies and has grown into a shared concern and commitment to improving professional teacher preparation for the many students in the program who, like me, are White, middle-class females teaching in diverse contexts. Over the last five years, we have been talking about how to create and incorporate a scope and sequence of experiences for prospective teachers to engage with the parents/caregivers and community during field work to develop culturally responsive "conceptions" (Milner, 2010, p. 188). Following Milner, we define conceptions as the "mindset, thinking, belief systems, attitudes, and overall understanding of the teaching and learning exchange" (p. 118). Thus, it is essential that teacher education addresses conceptions because they shape how educators use curricula and the corresponding instructional practices with P-12 students (Milner, 2010).

In order to better understand how preservice teachers in the program in which we both teach are prepared to engage with families and the parents/caregivers of the students they teach, particularly in diverse communities, we collected syllabi for each course in the program. We carefully read through the syllabus for each course to see if and how preservice teacher are provided opportunities to interact with families and parents/caregivers in the contexts where they complete fieldwork. In the next section, we describe the courses students in our program take, as well as descriptions of examples of some of the activities and experiences that comprise their 
fieldwork. We also provide examples of assignments for the courses that do not have a fieldwork component.

\section{Courses Across the Elementary Teaching Program}

While not mandatory, once admitted to the program, preservice teachers have the option to choose a focus if they wish to receive specialized training for a specific context. For example, students can select to enroll in the Urban Educators Cohort Program (UECP) or the Global Educators Cohort Program (GECP). Regardless of the route for certification, students are all required to take a core set of (nine) interdisciplinary courses that includes science, social studies, literacy, mathematics, art education, and children's and young adult literature. Six of the courses incorporate fieldwork as a component. The first three courses focus on topics such as learning and development; human diversity, power, and opportunity; and literacy learning in context.

For example, the course centered on human diversity, power, and opportunity is typically taken during students' second year in the program. This course requires that they complete 20 hours of service-learning in Lansing with teenagers or children who are culturally and/or linguistically different from themselves. Students receive a service-learning field placement in which they might work with an individual one-on-one such as helping with homework, in small groups leading a discussion, or similar activities. The supervisor at the site is not affiliated with the university but is asked to complete an evaluation form about the student's performance at the end of the semester. If students do not fulfill the service-learning requirement, they cannot pass the course.

During their third year, preservice teachers take one literacy course where they complete a junior practicum. This requires fieldwork two hours per week for a semester and is arranged by the university as the course is taught weekly in a local elementary school. Thus, students observe literacy instruction in an elementary classroom, facilitate small groups, and work with a "child study student." Using an ecological lens, they learn how to learn about an individual child using literacy assessment protocols and then analyze the data to inform instruction (Bronfenbrenner, 1979). Preservice teachers use these data to plan and teach lessons to the child study student. During the fourth year, in a reading methods course, the fieldwork component provides opportunities for students to observe and participate in literacy instruction by teaching small groups of children, assisting the classroom teacher, and trying out assessment tools. The program therefore prepares preservice teachers with two literacy courses before the student teaching internship year where they will take an additional reading methods course in the first semester.

Students take four core content-area methods courses in the last year of the program with substantial fieldwork. For example, throughout the year students are in schools four hours per week observing instruction, co-planning, and co-teaching mini-lessons in the disciplines of literacy, mathematics, social studies, and science. Some courses include a component where students learn about a child in the school context. In the mathematics methods course, for instance, students select a child who is different from them socio-culturally in some way. They observe the child, have informal conversations, and conduct an interview where the child is asked to solve a mathematical problem. Students then complete a reflection paper about the experience.

On the other hand, in an elementary science methods course, students begin the semester by visiting their school placement's neighborhood with special attention to details about the places and spaces where youth play or hang out, available resources for youth and their families, and what connections might be made to science. Focusing on pedagogy, students analyze their teaching and provide feedback to colleagues in professional learning communities using video 
and microteaching in the social studies methods course. Three required courses do not have a fieldwork component; however, instructors have incorporated various experiences that require students to explore the local community. The subject matter of these courses is children's and young adult literature, creative arts for children, and typical learning and development. Although students do not work with a particular child in a school or other context, as part of the art education course, they interview an inservice teacher about their practices regarding arts integration and they also take a class field trip to the MSU Museum.

Similarly, while taking the learning and development course, students enrolled in the GECP can participate in a two-day immersion learning experience in Dearborn, Michigan, a linguistically and culturally rich community, where they not only learn about the community but also the schools. Another example of a course assignment that asks students to visit the local community is through a semester-long book project that they complete in the children's and young adult literature course. Students seek resources (e.g., local public library, book store, school librarian) where they must find, read, and respond to a variety of books that includes various genres and titles by authors who have won popular awards as well as some that are less known.

Regardless of fieldwork as a course component, instructors focus on the community in the courses at the institution where we teach. A salient theme across the syllabi is community, both local and afar. However, while each course provides students with experiences exploring community, parents/caregivers are not considered an integral party of the community. In other words, the courses integrate the community and certain members of it but largely ignore the schools most important customers - the parents/caregivers of the children they serve! According to Williams Jr. (1992), a challenge that teacher educators face is how to conceptualize and make parental involvement an integral part of the elementary teacher preparation subject areas (e.g., reading, writing, computing, social studies, etc.).

Therefore, reflecting on the second author's experiences as a student in the same program and the first author's 28 years teaching in the program, we came up with some activities to incorporate family as a focus throughout the courses where we both teach undergraduate and graduate courses. We recognize that offering preservice teachers authentic opportunities to engage with families as a central tenet of teacher education progams is no easy task and thus perhaps one of the reasons it is typically neglected. The activities below (see Figure 3) provide preservice teachers experiences that engage, and for some, challenge their thinking around issues of diversity. We propose that in doing so, preservice teachers will be better equipped to teach diverse children and enhance their abilities to work with families. In other words, the activities are designed to help preservice teachers develop the culturally responsive conceptions that research has demonstrated, and from our own personal experiences, are imperative for teaching diverse children (Gay, 2018; Ladson-Billings, 1995; Milner, 2010; Villegas \& Lucas, 2002).

The activities can, and should be, modified with a critical eye across disciplines and focus on grade level (e.g., preK, elementary, middle, high school) and context (i.e., urban, rural, suburban). In addition, we are developing a website that contains foundational information on parent involvement (i.e., philosophical, theoretical, research, development, implementation, practice and evaluation literature) that our colleagues can access and share with students. No matter what course they are teaching, we are encouraging teacher educators to share this foundational information as a precursor to the parent involvement activity that students will be required to complete as part of their course. 
Creating opportunities for preservice teachers to engage with parents/caregivers in schools is challenging; therefore, teacher educators may need to expand traditional notions of fieldwork placements to include those where preservice teachers can actively engage with families. These contexts might include, but are not limited to daycare centers, churches, local community center, the Boys and Girls Club, YMCA, after-school care, sports and other related activities organized through a parks and recreation department or community education department. Additionally, one activity we have found productive in helping inservice teachers develop positive dispositions toward the children and parents/caregivers they work with is for them to write a thank you note to each child's parents/caregivers that includes a detailed description of the child's intellectual and social strengths. If the child's parents/caregivers speak a language other than English, preservice teachers can use tools such as Google Translate to communicate with a multilingual family (Edwards, Domke, \& White, 2017). 
Working with Racially, Culturally, and Linguistically Diverse Students

Figure 3: Examples of Activities that Focus on Parents/Caregivers in Elementary Teacher Preparation Courses

\begin{tabular}{|c|c|}
\hline Topic & Parent/Community Focused Activity \\
\hline Learning and Development & $\begin{array}{c}\text { Students learn what sociocultural consciousness } \\
\text { (Villegas \& Lucas, 2002) is and examine who they } \\
\text { are as a learner to understand how their experiences } \\
\text { might influence their view of learning and } \\
\text { development by interviewing a parent/caregiver } \\
\text { who they feel supported their own language and } \\
\text { literacy development. } \\
\text { Students can reflect on how their own social and } \\
\text { cultural practices might affect their perceptions } \\
\text { about the students they teach, particularly if the } \\
\text { students are linguistically and culturally different } \\
\text { from themselves. } \\
\end{array}$ \\
\hline Children's and Young Adult Literature & $\begin{array}{l}\text { Create a family profile for a school (e.g., preK, } \\
\text { elementary, middle, or high) in the area or a context } \\
\text { that students are interested in seeking employment. } \\
\text { Visit the school or public library (in person or } \\
\text { online) and complete a profile of the available } \\
\text { materials to see how they compare with the family } \\
\text { profile that students constructed. } \\
\text { Questions that students might reflect on: Do the } \\
\text { materials reflect the cultures of the student } \\
\text { population? Are materials available for } \\
\text { parents/caregivers? If so, are they culturally } \\
\text { relevant? If materials are not available, what } \\
\text { message might be conveyed about } \\
\text { parents/caregivers? Students can research and } \\
\text { develop a list of books that could be included in the } \\
\text { library's collection that reflect the school's } \\
\text { population. }\end{array}$ \\
\hline Art Education & $\begin{array}{c}\text { Students visit a local school and interview the art } \\
\text { teacher to find out what type of artwork children } \\
\text { have recently completed or will soon finish. Next, } \\
\text { students using digital technology tools to create a } \\
\text { virtual art show that displays a child's or a group of } \\
\text { children's art work that the teacher can share with } \\
\text { parents/caregivers. The virtual art show can include } \\
\text { short interviews with the artist of each original } \\
\text { piece. }\end{array}$ \\
\hline
\end{tabular}




\begin{tabular}{|c|c|}
\hline Mathematics & $\begin{array}{l}\text { Students can interview a classroom teacher about } \\
\text { ways that children can engage in mathematics } \\
\text { outside of school that builds on their cultural } \\
\text { practices. Students will also need to develop a funds } \\
\text { of knowledge profile about parents/caregivers in the } \\
\text { classroom. If possible, students might interview or } \\
\text { survey parents/caregivers to find out about families' } \\
\text { funds of knowledge. Next, students can use digital } \\
\text { technologies to create for example, a video, a } \\
\text { webpage, a newsletter, or a free app to communicate } \\
\text { these ideas with parents/caregivers. If } \\
\text { parents/caregivers speak another language, students } \\
\text { can use online translation tools. }\end{array}$ \\
\hline Social Studies & $\begin{array}{l}\text { To expand traditional notions of context for } \\
\text { fieldwork, students can explore the local area } \\
\text { beyond schools for places they can visit to learn } \\
\text { about children, parents/caregivers, and community } \\
\text { be creating a demographic profile of the context } \\
\text { (see Edwards 2004; 2009). Some possibilities might } \\
\text { include a YMCA, after-school sports, clubs, and } \\
\text { classes through the local community education } \\
\text { department, Students then develop a social studies } \\
\text { lesson that connects children's out-of-school lives to } \\
\text { the content. }\end{array}$ \\
\hline Literacy & $\begin{array}{l}\text { Students can gather Parent Stories (see Edwards, } \\
\text { Pleasants, \& Franklin, 1999) for a child study } \\
\text { student they are working one-on-one with to } \\
\text { understand that child's funds of knowledge (Moll, } \\
\text { Amanti, Neff, \& Gonzalez, 1992). Parent stories can } \\
\text { be collected in person or using digital technologies } \\
\text { such as video conferencing, email, or a survey using } \\
\text { Google Docs. This activity is interdisciplinary. }\end{array}$ \\
\hline Science & $\begin{array}{l}\text { Teacher educators can reach out to local elementary } \\
\text { schools and meet with classroom teachers to find } \\
\text { out what types of school-wide or grade-level science } \\
\text { activities occur during the school year. An } \\
\text { established partnership between the university and } \\
\text { teachers could provide a segue for preservice } \\
\text { teachers to assist with science-related activities } \\
\text { before, during, or after school. For example, } \\
\text { preservice teachers could help children and families } \\
\text { prepare a science fair project, plan and help run a } \\
\text { family science night, provide tutoring, run an after- } \\
\text { school science club, etc. }\end{array}$ \\
\hline
\end{tabular}




\begin{tabular}{|l|c|}
\hline \multirow{1}{*}{ Human Diversity, Power, and } & $\begin{array}{c}\text { Students visit and interview a pediatrician to find } \\
\text { out what types of support are offered to } \\
\text { parents/caregivers regarding school. Using that } \\
\text { information, along with the pediatrician, students } \\
\text { identify a topic, research it, and develop a brochure } \\
\text { or pamphlet covering a need that is relevant to the } \\
\text { families who are customers at the clinic. With } \\
\text { permission, copies of the brochures can be placed in } \\
\text { the pediatrician's office. Alternatively, students } \\
\text { could prepare a short survey that parents/caregivers } \\
\text { could fill out at a pediatrician's office, a local } \\
\text { school, or a preschool about what types of support, } \\
\text { if any, they would like to receive from their child's } \\
\text { school. Students could then analyze the data and } \\
\text { develop a list of possible solutions. Another } \\
\text { possible activity is for students to create a } \\
\text { demographic profile (see Edwards, 2004; 2009) of } \\
\text { the parents/caregivers in a school context. Then they } \\
\text { can analyze the data to assess the school to see if it } \\
\text { is welcoming atmosphere that reflects the profile } \\
\text { (see Edwards, Domke, \& White, 2017). }\end{array}$ \\
\hline
\end{tabular}

\section{Conclusion}

Despite teachers' geographical location, one thing is certain: they face diversity. Diversity is not only a challenge for teachers of European ancestry but for all teachers who encounter children with characteristics and backgrounds different from their own. African Americans teach Mexican American children, able-bodied teachers teach children with physical disabilities, Puerto Ricans teach Irish American children, teachers fluent in English instruct children fluent only in Cantonese, and middle-class teachers serve children who are poor. Even when teachers and young children share a common cultural, linguistic, ethnic, racial, or social class background, they may not be able to translate their own experiences into effective educational practices that benefit children.

Classroom teachers must face the reality that they will most likely teach students who come from different cultural, ethnic, linguistic, racial, and social-class backgrounds than their own. One point we wish to make clear is that it is imperative that preservice teachers understand that parental involvement is not the panacea for racial achievement (Robinson \& Harris, 2014). Rather, racial achievement gaps are due to structural and system inequities (Milner, 2015). It is particularly important for preservice teachers to understand the ways that institutions like school have historically underserved children affected by poverty, whose first language is not English, or who are of color (Milner, 2015).

However, we believe that one step toward closing the racial achievement gap and inequities is to bridge family resources and school curriculum to enhance student achievement if and when teachers have the conceptions to learn what those resources are and how to incorporate them. This way, we propose, teachers will not only honor students' identities but also begin to see students' culture, home language, and race/ethnicit as strengths, indicating that they are capable learners of school literacy whose prior experiences are different and not deficient. We 
also view students' home literacies as a place to begin leveraging families' funds of knowledge. The message then that we do want preservice teachers to have is that learning to work alongside parents/caregivers requires a "guided approach" that considers race, social, class, and culture (Robinson \& Harris, 2014, p. 231). Hence, we believe that preparing educators who make a difference in our diverse classrooms must include helping teachers learn how to establish open, honest, and productive relationships with families (Edwards, 2016). Delpit (1995) explains it best when she stated,

Teachers cannot hope to begin to understand who sits before them unless they can connect with the families and communities from which their children come. To do that it is vital that teachers and teacher educators explore their own beliefs and attitudes about non-white and non-middle class people. (p. 209)

Exploring such beliefs is not something teachers or teacher educators have routinely embraced. However, now is the time! 
Working with Racially, Culturally, and Linguistically Diverse Students

\section{References}

Beane, D. B. (1990). Say YES to a youngster's future: A model for home, school, and community partnership. The Journal of Negro Education, 59(3), 360-374.

Becker, H. J., \& Epstein, J. L. (1982). Parent involvement: A study of teacher practices. Elementary School Journal, 83, 85-102.

Bronfenbrenner, U. (1979). The ecology of human development. Cambridge, MA: Harvard University Press

Corno, L. (1989). What it means to be literate about classrooms. In D. Bloome (Ed.), Classroom and literacy (pp. 29-52). Norwood, NJ: Ablex Publishing Corporation.

Cummins, J. (1986). Empowering minority students: A framework for intervention. Harvard Educational Review, 56, 18-36.

Delpit, L. (1995). Other people's children: Cultural conflict in the classroom. New York: The New Press.

Delgado-Gaitan, C. (1991). Involving parents in the schools: A process of empowerment. American Journal of Education, 100(1), 2-46.

Edwards, P. A. (1991). Fostering early literacy through parent coaching. In E. Hiebert (Ed.), Literacy for a diverse society: Perspectives, programs, and policies (pp. 199-213). New York: Teachers College Press.

Edwards, P. A. (1993). Parents as Partners in Reading: A Family Literacy Training Program. Second Edition. Chicago: Childrens Press.

Edwards, P. A. (1996). Creating sharing time conversations: Parent and teachers work together. Language Arts, 73, 344-349.

Edwards, P. A. (2004). Children literacy development: Making it happen through school, family, and community involvement. Boston: Allyn \& Bacon.

Edwards, P. A. (2009).Tapping the potential of parents: A strategic guide to boosting student achievement through family involvement. New York: Scholastic.

Edwards, P. A. (2011). Differentiating family supports. In S. Redding, M. Murphy, \& P. Sheley (Eds.), Handbook on Family Community Engagement (pp. 113-115). Charlotte, NC: Information Age Publishing.

Edwards, P. A. (2016). New ways to engage parents: Strategies and tools for teachers and leaders, $K-12$. New York: Teachers College Press.

Edwards, P. A., Domke, L., White, K. L. (2017). Closing the parent gap in changing school districts. In S. Wepner \& D. Gomez (Eds.), Challenges facing suburban schools: Promising responses to changing student populations (pp. 109-121). New York: Rowman \& Littlefield.

Edwards, P. A., McMillon, G. T., \& Turner, J. D. (2010). Change is gonna come: Transforming literacy education for African American students. New York: NY. Teachers College Press.

Edwards, P. A., Pleasants, H. M., \& Franklin, S. H. (1999). A path to follow: Learning to listen to parents. Portsmouth, NH: Heinemann.

Epstein, J. L. (1987). Parent involvement: State education agencies should lead the way. Community Education Journal, 14(4), 4-10.

Epstein, J. L. (2001). School, family, and community partnerships. Boulder, CO: Westview.

Epstein, J. L., \& Becker, H. J. (1982). Teachers' reported practices of parent involvement: Problems and possibilities. Elementary School Journal, 83, 103-113. 
Fear, K. L., \& Edwards, P. A. (1995). Building a democratic learning community within a PDS. Teaching Education, 7(2), 12-24.

Fletcher, R. (1966). The family and marriage in Britain. Harmondsworth: Penguin.

Florio-Ruane, S. (1994). The future teachers' autobiography club: Preparing educators to support literacy learning in culturally diverse classrooms. English Education, 26(1), 52-66.

France, M. G., \& Meeks, J. W. (1987). Parents who can't read: What the schools can do. Journal of Reading, 31, 222-227.

Gay, G. (2018). Culturally responsive teaching: Theory, research, and practice (3rd ed.). New York: Teachers College Press.

Gordon, I. J. (1969). Reaching the child through parent education: The Florida approach. Gainesville, FL: Institute for the development of human resources, College of Education, University of Florida.

Handel, R. E. (1992). The partnership for family reading: Benefits for families and schools. The Reading Teacher, 46(2), 117-126.

Hess, R. D., \& Shipman, V. (1965). The socialization of cognitive modes in children. Child Development, 36, 461-479.

Hollins, E. R. (1996). Culture in school learning: Revealing the deep meaning. Mahwah, NJ: Lawrence Erlbaum Associates.

Keenan, J. W., Willett, J., \& Solsken, J. (1993). Focus on research: Constructing an urban village: School/home collaboration in a multicultural classroom. Language Arts, 70, 204214.

Knapp, J. S., Turnbull, \& Shields, P. M. (1990, September). New directions for educating the children of poverty. Educational Leadership, 48(1), 4-8.

Krevotics, J., \& Nussel, E. J. (Eds.). (1994). Transforming urban education. Boston: Allyn \& Bacon.

Kochan, F. \& Mullins, B. K. (1992). Teacher education: Linking universities, schools, and families for the twenty-first century. In L. Kaplan (Ed.), Education and the family (pp. 266-272). Boston, MA: Allyn and Bacon.

Lareau, A. (1989). Home advantage: Social class and parental intervention in elementary education. New York: Falmer Press.

Lareau, A. (2000). Home advantage: Social class and parental intervention in elementary education. ( $2^{\text {nd }}$ ed.). Lanham, MD: Rowman, \& Littlefield Publishers, Inc.

Lynch, A. (1992). The importance of parent involvement. In L. Kaplan (Ed.), Education and the family. Boston: Allyn and Bacon.

Mapp, K. (1997). Making family-school connections work. The Education Digest, 6(4), 36-39.

Milner, H. R. (2010). What does teacher education have to do with teaching? Implications for diversity studies. Journal of Teacher Education, 60(1/2), 118-131.

Milner, H.R. (2013). But subject matter-content is not enough. Urban Education, 48(3), 247-349.

Moll, L. C., Amanti, C., Neff, D., \& Gonazalez, N. (1992). Funds of knowledge for teaching: Using a qualitative approach to connect home and classrooms. Theory Into Practice, 31(2), 132-141.

Pizzo, P. D. (1990, September). Family-centered head start for infants and toddlers: A renewed direction for the project head start. Young Children, 45(6), 30-39.

Potter, G. (1989). Parent participation in the language arts program. Language Arts, 66(1), 21-28.

Robinson, K., \& Harris, A. L. (2014). The broken compass: Parental Involvement with children's education. Cambridge, MA: Harvard University Press. 
Working with Racially, Culturally, and Linguistically Diverse Students

Seefeldt, C. (1985). Communicate with curriculum. Day Care and Early Education, 13(2), 2225.

Shockley, B., Michalove, B., \& Allen, J. (1995). Engaging families: Connecting home and school literacy communities. Portsmouth, NH: Heinemann.

Holmes Group. (1986). Tomorrow's teachers: A report of the Holmes group. Retrieved from http://files.eric.ed.gov/fulltext/ED270454.pdf

Holmes Group. (1990). Tomorrow's schools of education: A report of the Holmes group. Retrieved from http://files.eric.ed.gov/fulltext/ED399220.pdf

Villegas, A. M., \& Lucas, T. (2002). Preparing culturally responsive teachers: Rethinking the curriculum. Journal of Teacher Education, 53(1), 20-32.

Williams, Jr., D. L. (1992). Parental involvement in teacher preparation: Challenges to teacher education. In L. Kaplan (Ed.), Education and the family (pp. 243-254). Boston, MA: Allyn and Bacon.

\section{Notes}

${ }^{1}$ Parent Teacher Association (PTA) and Parent Teacher Organization (PTO) are parent groups in the U.S. formed to encourage interaction between the school and families to improve students' educational experience.

${ }^{2}$ Parent Information Meeting: A group meeting where teachers and parents collaborate on a grade-level literacy project.

${ }^{3}$ Parent Stories: Narratives gained from open-ended interviews. In these interviews, parents respond to questions designed to provide information about traditional and nontraditional early literacy activities and experiences that have happened in the home.

${ }^{4}$ Scope and Sequence: Grade-level family involvement activities that are developmentally based on shared decision making and built around the elementary literacy curriculum.

${ }^{5}$ The U.S. government provides additional funding to schools with high numbers of children from lowincome families. 